\title{
Impact of Capital Structure on Profitability: A Comparative Study of Islamic and Conventional Banks of Pakistan
}

\author{
Noor ul QAYYUM ${ }^{1}$, Umara NOREEN $^{2}$
}

Received: July 21, 2019 Revised: September 16, 2019 Accepted: September 24, 2019

\begin{abstract}
This study has two main purposes; first, it examines the effect of capital structure on profitability of Islamic and conventional banks; second, it determines that whether the capital structure of Islamic and conventional banks is same or not. A sample of ten banks was taken over the period 2006-2016. Independent samples T-test was used for finding the comparison between the capital structure of Islamic and conventional banks while for assessing the impact of capital structure on profitability, regression analysis (Fixed effects model) was used. Results showed that the capital structure of both types of banks was similar except for bank size which differed significantly. Moreover, ROA was negatively correlated to the capital structure of both conventional and Islamic banks. In contrast, ROE was positively correlated to the capital structure of both conventional and Islamic banks. In addition to that, two explanatory variables were positively correlated while two were negatively correlated to EPS for both Islamic and conventional banks. This study proves the existence of prominent theories of capital structure (pecking order theory and trade-off theory) for both conventional and Islamic banks in Pakistan and also validates the economies of scale.
\end{abstract}

Keywords : Capital Structure, Profitability, Islamic Banks, Conventional Banks, Pakistan

JEL Classification Code : G01, G02, G03

\section{Introduction}

Capital structure is a verified interesting topic for the researchers and has been studied from different perspectives. Researchers have rushed towards this topic when Modigliani and Miller (1958) proposed the theorem of irrelevancy. Gharaibeh (2015), Goyal (2013), Hailu (2015), Ibrahim (2015), Rafique (2011), Sakti, Tareq, Saiti, and Akhtar (2017), Kim and Lee (2017), Meero (2015) and many more have studied capital structure. According to Brounen and

1 First Author and Corresponding Author, Department of Management Sciences, COMSATS University, Islamabad, Pakistan. [Postal Address: Aquaculture and Fisheries Program, ASI, NARC, ChakShahzad, Park Road, Islamabad, 44000, Pakistan] Email: noorqayyum@yahoo.com

2 Assistant Professor, Finance Department, College of Business Administration, Ext: 8871

Prince Sultan University, Women Campus, Riyadh, Saudi Arabia. Email: unoreen@psu.edu.sa

(c) Copyright: Korean Distribution Science Association (KODISA)

This is an Open Access article distributed under the terms of the Creative Commons Attribution Non-Commercial License (http://Creativecommons.org/licenses/by-nc/4.0/) which permits unrestricted noncommercial use, distribution, and reproduction in any medium, provided the original work is properly cited.
Eichholtz (2001), the most controversial debate in the corporate finance literature is the issue of capital structure. According to Chechet and Olayiwola (2014), organizations can raise funds by two means i.e. internally or externally. Internally, an organization tends to finance its operation from retained earnings while externally the options of raising debt and issuance of shares are available. The capital structure consists of a company's equity and debt (Arulvel\&Ajanthan, 2013). Moreover, Addae, Nyarko-Baasi, and Hughes (2013) declare that profitability, firm's value, shareholder's wealth and value are all used interchangeably because they show the creation of wealth for shareholders. According to Zeitun and Tian (2007), the firm's revenue can be maximized if the firm's managers can identify the optimal capital structure. Zarrouk, Jedidia, and Moualhi (2016) identified the differences between Islamic and conventional banks. Islamic banks' activities should comply with Shariah and Quran and don't believe in interest in contrast to conventional banks.

This research mainly focuses on two research questions:

Q.1: Is Islamic banks' capital structure the same as conventional banks' one? 
Q.2: What is the impact of capital structure on the performance of Islamic and conventional banks in Pakistan?

The rest of the study is as follows: Section 2 is about Literature Review. Materials and methods are described in section 3. Section 4 is allocated to results and discussion. Section 5 discusses conclusion and section 6 is about recommendations and future implication.

\section{Literature Review}

Capital structure has been studying by the researchers to find out the optimal capital structure since long; and for this purpose, many theories such as Modigliani and Miller (MM) theory, the static trade-off theory and pecking order theory are presented. The capital structure topic drew the attention of the researchers when MM presented their theory of irrelevancy. The work of the researchers across the globe shows that for some organizations there exists a positive relationship between the capital structure and the performance while for others, it shows a negative relationship (Muhammad, Shah, \& Islam, 2014). This is the reason an effort is being made to study this relationship for Pakistani banks.

Moreover, the literature on the topic of capital structure is available with the respect to profitability but a major part of the literature goes to developed countries (Meero, 2015). There is still a need for researching this topic in developing countries like Pakistan because the existing literature lacks the comparison of two types of banks in terms of profitability and capital structure. Moreover, in Pakistan, up to some context, the impact of capital structure on profitability has been studied as the work of Zafar, Zeeshan, and Ahmed (2016) and Qamar, Masood, and Khan (2016) show, but that is purely on general banking without discrimination of commercial and Islamic banks. Hence, this study will not only show the influence of capital structure on Islamic and commercial banks' profitability but will also find out the difference/similarity of the capital structure of two types of banks. In addition to that, the comparison of Islamic and conventional banks in Pakistan in terms of profitability and capital structure will cover the gap in the existing finance and accounting's literature, especially in Pakistan.

\subsection{Theoretical Background}

The decision of the percentage of debt and equity in the capital structure is paramount for all organizations because this decision directly affects the performance of the organization. If the balance between equity and debt is kept rationally then it would boost the performance of the organization; otherwise, it would lead the organization towards the bankruptcy. The two prominent theories regarding capital structure, which are found in literature, are trade-off theory and pecking order theory.

\subsubsection{Trade-off Theory}

Trade-off theory focuses on the balance between the cost and benefit of the debt. The company should consider the cost and benefit attached to the debt and should try to get the optimal capital structure. The benefit an organization can take by adding some debt in its capital structure is the benefit of the tax shield. On the other hand, the costs, attached to the debt, are bankruptcy cost and nonbankruptcy cost like the cost of investors, cost of employees, cost of suppliers, and cost of customers etc. Trade-off theory suggests a positive relationship between a firm's performance and debt. The same positive relationship between profitability and leverage is shown by researchers and thus proves the relevancy of trade-off theory.

Appiadjei (2014) examined the influence of capital structure on performance of the firms for all 35 companies listed on Ghana stock exchange for the period 2004-2008 and observed that there was a direct relation between short term debt and profitability and positive relation between long term debt and profitability. Anafo, Amponteng, and Yin (2015) also analyzed the relationship between capital structure and profitability for Ghanaian banks during 20072013. They found that there was a direct relation between short-term debt and ROA (return of assets), ROE (return on equity), and EPS (earning per share); and reverse relation was found between the long term debt and dependent variables of the study except for EPS. Moreover, Zafar et al. (2016) investigated the influence of capital structure on banking performance for 25 banks listed on Karachi stock exchange and found the positive relationship between debt to assets and performance indicators such as ROA, ROE and EPS.

In addition to that, Addae et al. (2013) examined the association between profitability and capital structure during 2005-2009 for Ghana. A regression model was used for the estimation of data. The result revealed that there was a positive association between short term debt and profitability. Similarly, Rajha and Alslehat (2014) tested the influence on performance by capital structure of Jordanian Islamic banks during 1998 to 2012. The relationship between dependent and independent variables was found out by multiple regressions. The result showed that equity ratio, total asset and financing to total assets had a direct effect on performance. The same positive relationship between leverage and profitability was also identified by Chisti, Ali, and Sangmi (2013); Bitar, Hassan, Pukthuanthong, and Walker (2016); Pratomo and Ismail (2007); and Akhtar, Ali, and Sadaqat (2011).

\subsubsection{Pecking Order Theory}

According to pecking order theory, there are three possibilities for financing an organization: an internal source of fund, debt, and equity. This theory places the internal source of fund at the top of the priority, but the problem 
arises when the internal fund is exhausted. Externally, organizations seek two ways of financing. First, to get funds from credit holders and the second way is to issue shares. Issuance of shares to get the finance is placed in the last of hierarchy. Pecking order theory suggests a negative relation between leverage and profitability which is shown by researchers.

Hailu (2015) explored the influence of capital structure on the performance of conventional banks in Ethiopia for the period 2001-2012 and observed that debt to asset ratio had a negative relation to the profitability. Nguyen and Nguyen (2015) examined the influence of capital structure on the performance in Vietnam for 147 listed firms during 2006-2014. The result indicated that all leverage variables were negatively correlated to the firm's performance. Chechet and Olayiwola (2014) analyzed the relationship between the capital structure and profitability for the quoted firms in Nigeria for the period 2000-2009 and showed that the debt ratio was negatively related to profitability.

Goyal (2013) sought to study the capital structure's impact on the profitability of Indian's listed banks during 2008-2012 and found an indirect relationship between profitability and capital structure. Likewise, the same negative relationship between leverage and profitability was also identified by Chechet and Olayiwola (2014); Lee and Liu (2015); Hasan, Ahsan, Rahaman, and Alam, (2014); Qamar et al. (2016); and Zeitun (2012).

\subsection{Research Hypotheses}

The motive of the study is not only to find an influence of capital structure on profitability of Islamic and conventional banks in Pakistan but also to compare the capital structure of Islamic and commercial for the period 2006-2016. The null and alternate hypotheses of this study are given below:

\subsubsection{Comparison of Islamic and Conventional banks}

H0: Capital structure of conventional and Islamic banks is the same.

H1: Capital structure of conventional and Islamic is different.

The first hypothesis of this study is to find out whether the capital structure of commercial and Islamic banks in Pakistan is the same or different.

\subsubsection{Null hypotheses for finding the impact of capital structure on profitability are as followed}

H10: There is no significant impact of capital structure on ROE of Islamic and conventional banks.
H20: There is no significant impact of capital structure on the ROA of Islamic and conventional banks.

H30: There is no significant impact of capital structure on EPS of Islamic and conventional banks.

\section{Materials and Method}

Eleven years of data of the sampled ten banks has been composed of the financial statements of the concerned banks during 2006-2016. The population of this particular study is all banks operating in Pakistan i.e. conventional and Islamic banks. The five conventional banks which are part of the study are National bank of Pakistan (NBP), Habib bank limited (HBL), United bank limited (UBL), Muslim commercial bank (MCB), and Allied bank Limited (ABL). The sample Islamic banks in the study are Meezan bank, Bank Islami, Albaraka Islamic bank, Dubai Islamic bank and Burj bank. To carry out the objectives of this research, different software and methods have been used. For statistical purpose, SPSS 16 and E-View9 versions are used and for calculation, MS Excel is used. Panel data is analyzed in many ways: descriptive statistics, t-test with the $95 \%$ confidence level and multiple regressions.

\subsection{Model Specification}

This study tries to find out the influence of capital structure on profitability of the sampled banks. Capital structure is determined by three financial ratios: debt to equity ratio (DTE), debt to assets (DTA) and shareholder equity ratio; while profitability/performance is determined by three other financial ratios: return on equity (ROE) and earnings per share (EPS), Return on assets (ROA). This study has used the following model:

$$
\mathrm{Y}_{\mathrm{it}}=\beta_{0}+\beta_{1} \mathrm{D}_{\mathrm{it}}+\mathrm{e}_{\mathrm{it}}
$$

where $Y=$ dependent variable, $\beta 0$ shows intercept, $\beta 1=$ slope, $\mathrm{D}=$ explanatory variable, e shows error term, $\mathrm{I}=$ no. of banks and $\mathrm{t}=$ no. of periods. Where "I" represents the cross-sectional element of the study while " $t$ " represents the time series element in this study.

Equation 1: Return on asset

$$
\begin{aligned}
\text { ROA }_{i t}= & \beta_{0 i t}+\beta_{1} \text { TDTTA }_{i t}+\beta_{2} \text { ETTA }_{i t} \\
& +\beta_{3} \text { TDTE }_{i t}+\beta_{4} \text { size }+\varepsilon_{\text {it }}
\end{aligned}
$$

Equation 2: Return on equity

$$
\begin{aligned}
\text { ROE }_{i t}= & \beta_{0 \text { it }}+\beta_{1} \text { TDTTA }_{\text {it }}+\beta_{2} \text { ETTA }_{\text {it }} \\
& +\beta_{3} \text { TDTE }_{i t}+\beta_{4} \text { size }+\varepsilon_{\text {it }}
\end{aligned}
$$


Equation 3: Earnings per Share

$$
\begin{aligned}
\mathrm{EPS}_{\text {it }}= & \beta_{0 \mathrm{it}}+\beta_{1} \text { TDTTA }_{\text {it }}+\beta_{2} \text { ETTA }_{\text {it }} \\
& +\beta_{3} \text { TDTE }_{\text {it }}+\beta_{4} \text { size }+\varepsilon_{\text {it }}
\end{aligned}
$$

\subsection{Variables}

The dependent variables used in this research are return on equity (ROE), return on assets (ROA) and earnings per share (EPS) which determine profitability. This determination of profitability has been used by many researchers like Anafo et al. (2015), Mujahid and Akhtar (2014), Zafar et al. (2016) and many others. Likewise, independent variables included in the study are debt to equity, debt to assets, bank size and shareholder equity to total assets and the same independent variables were taken by different researchers like Meero (2015).

\section{Results and Discussion}

\subsection{Descriptive Statistics of Islamic and Conventional Bank}

\subsubsection{Commercial Bank's Descriptive Statistics}

The mean value of ROA in this study is $2 \%$. This $2 \%$ return on assets goes to investors. This value is very low and it means that commercial banks are not generating enough profit. The mean value of Return on equity is 0.24. Shareholders would get a $24 \%$ return in the net profit. The mean value of Earning per share (EPS) is 15.4 which show the profit of investors per share. Moreover, the mean worth of debt to equity is 10.83 which give us the percentage of $1083 \%$. This is a very handy ratio which shows the capital of shareholders in the business as well as the capital of creditors in the business. The high value of this ratio shows that banks in Pakistan are highly dependent on debt. Debt to asset ratio, 0.89, illustrates how much assets of the banks are financed by debt. The shareholder equity ratio is also a part of the research. This ratio gives us the clue that how much assets of the organization are financed by the shareholders. By this ratio, we have come to know that $9.7 \%$ of assets of the conventional banks have been provided by the equity holders while the rest of the assets have been financed by the creditors. Along with this, bank size values are taken by taking the $\log$ of assets for the particular periods; average worth of the bank size is 8.92. The descriptive statistic of commercial banks is given in Table 1.

Table 1: Descriptive statistics

\begin{tabular}{|c|c|c|c|c|c|}
\hline \multicolumn{6}{|c|}{ Descriptive statistics of Conventional banks and Islamic banks } \\
\hline & $\begin{array}{c}\mathrm{N} \\
\text { (Con/lsI) }\end{array}$ & $\begin{array}{l}\text { Minimum } \\
\text { (Con/IsI) }\end{array}$ & $\begin{array}{c}\text { Maximum } \\
\text { (Con/IsI) }\end{array}$ & $\begin{array}{c}\text { Mean } \\
\text { (Con/lsI) }\end{array}$ & $\begin{array}{l}\text { Std. Deviation } \\
\text { (Con/lsI) }\end{array}$ \\
\hline ROA & $55 / 52$ & $0.004 /-.034$ & $0.043 / 0.019$ & $0.0207 / 0.0004$ & $0.007 / 0.012$ \\
\hline ROE & $55 / 52$ & $0.054 /-0.234$ & $0.483 / 0.346$ & $0.249 / 0.036$ & $0.075 / 0.125$ \\
\hline EPS & $55 / 50$ & $2.480 /-2.190$ & $26.170 / 5.55$ & $1.540 \mathrm{E} 1 / 0.624$ & $6.283 / 1.678$ \\
\hline Debt to equity & $55 / 53$ & $1.141 / 0.003$ & $16.599 / 22.284$ & 1.083E1/9.825E0 & $2.822 / 5.367$ \\
\hline Debt to assets & $55 / 53$ & $0.847 / 0.003$ & $0.951 / 0.953$ & $0.895 / 0.850$ & $0.024 / 0.161$ \\
\hline Equity to assets & $55 / 53$ & $0.056 / 0.042$ & $0.755 / 0.996$ & $0.097 / 0.147$ & $0.0921 / 0.160$ \\
\hline Bank size & $55 / 53$ & $8.40 / 6.43$ & $9.40 / 8.82$ & $8.921 / 70745$ & $0.2275 / 0.495$ \\
\hline Valid N & $55 / 50$ & & & & \\
\hline
\end{tabular}

Con: Conventional, Isl: Islamic, ROA: Return on Assets, ROE: Return on Equity, EPS: Earning per share

\subsubsection{Descriptive Statistics of Islamic Banks}

The mean value of Return on assets (ROA) in this study is 0.0004 which is $0.04 \%$. It means that every rupee invested by investors in Islamic banks can get the return of 0.0004 . This ratio specifically emphasizes on bank's earning by investing in assets. Both types of banks in this study are not generating enough profit and ROA value is very low, but comparatively performance of commercial banks is good than Islamic banks. The mean value of Return on equity (ROE) is 0.036 which shows that against each rupee of investment by shareholders; they get 0.036 in return. It is calculated by net income divided by shareholder equity. The mean value of Earnings per share in this study is 0.624. Earnings per share show that how much return an investor gets per share at the time of announcing dividends. The mean value of the sampled Islamic banks in this study is
0.624 which tells us that an investor can get 0.624 returns by holding the share of Islamic banks in Pakistan. The mean value of Debt to equity in this study is found as 9.82. Debt to equity ratio tells us the providence of the funds in the company by the shareholders and the creditors. Like conventional banks, the result of this ratio for Islamic banks is also high. This means that against one rupee of shareholders, creditors have provided 9.82 rupees. Mean value of debt to assets for the sampled Islamic banks is 0.850 which is $85 \%$. And it means $85 \%$ of assets are financed by debt. Among the independent variables, one is the equity holder ratio which is total shareholder's equity by total assets. This focuses on the funds provided by the shareholders to finance the bank's assets. The mean value of shareholder equity ratio is calculated as 0.147 which shows that $14.7 \%$ of the assets go to the shareholders while the rest 
of the assets are financed by the debt. Besides all these ratios, the last one is bank size, whose mean value is 7.74 . The descriptive statistic of Islamic banks is given in Table 1.

\subsection{Comparison of Capital Structure between Commercial and Islamic Banks}

For comparison between the capital structure of Islamic and conventional banks, we ran the test of independent samples T-test. The same test was run by Meero (2015). This study uses four independent variables like debt to equity, equity to assets, debt to assets, and size of the bank. Independent sample test was run for each of them individually and it was focused that whether the capital structure of the sampled banks was the same or different.

This independent samples test, in which our major focus would be on Levene's test, has been run on SPSS software.
This test by default considers two hypotheses i.e. for the first one, variances are considered equal while for other hypothesis, variances are not considered equal. In the Levene's test, we would consider just one row based on the significant value which is also called the p-value. Levene's test of all independent variables is given in Table 2.Table 2shows Levene's test of just one independent variable i.e. Debt to Equity and for the remaining variables, required values from the software-generated tables have been extracted to find out the comparison of capital structure between commercial and Islamic banks.

From Table 2, we could see that all the variables, except the bank size, have similar capital structure. The similarity of both types of banks in term of capital structure can be due to the fact that both are operating in the same environment having the same rules and regulations and compulsions from the government of Pakistan.

Table 2: Levene's Test of all independent variables

\begin{tabular}{|c|c|c|c|}
\hline Variable & $\begin{array}{l}\text { Levene's test } \\
\text { significant value }\end{array}$ & 2 tailed significant value & $\begin{array}{l}\text { Result (similarity/difference between Islamic } \\
\text { conventional banks' capital structure) }\end{array}$ \\
\hline Debt to Equity & 0.000 & 0.226 & Similar capital structure \\
\hline Debt to assets & 0.000 & 0.49 & Almost similar capital structure \\
\hline Equity to assets & 0.003 & 0.54 & Similar capital structure \\
\hline Bank size & 0.000 & 0.000 & Significantly difference \\
\hline
\end{tabular}

\subsection{Regression Analysis}

To find an influence on performance by capital structure of Islamic and conventional banks in Pakistan, we have first to find out the appropriate model for our study i.e. either random-effects model or fixed-effects model. We have run the Hausman test which is shown in appendix 4 and came to know that the fixed-effects model is appropriate because the p-value in the Hausman test is below than 5\%. Furthermore, for some variables, we have taken log or lag to remove the problem of normality or autocorrelation respectively. The same techniques have been used by Zafar et al. (2016), Qamar et al. (2016) and many others.

\subsubsection{Assumptions of the Classical Linear Regression Model}

This part of the study presents the assumptions of the classical linear regression model. The main assumptions are multicollinearity, autocorrelation, heteroscedasticity, and normality. All the mentioned tests are run on Eview 9 for both commercial and Islamic banks and none of them has shown any problem in the data.

\subsubsection{Interpretation of Equation 1}

$$
\begin{aligned}
\mathrm{ROA}_{\text {it }}= & \beta_{0 \mathrm{it}}+\beta_{1} \text { TDTTA }_{\text {it }}+\beta_{2} \mathrm{ETTA}_{\text {it }} \\
& +\beta_{3} \text { TDTE }_{\text {it }}+\beta_{4} \text { size }+\varepsilon_{\text {it }}
\end{aligned}
$$

Appendix 5 illustrates the relationship between ROA and independent variables used in this study for both Islamic and conventional banks. Debt to equity, debt to asset, equity to assets and size were used for the determination of capital structure while profitability was measured by ROA in equation 1 . The $\mathrm{R}$-square is $62 \%$ for conventional banks and $37 \%$ for Islamic banks. R-square percentage means that $62 \%$ ( conventional), and $37 \%$ ( Islamic) of profitability (ROA) is measured by the explanatory variables used in this study. R-square for conventional banks is fairly well and shows that model is fit but the same model for Islamic banks is not as good as for the conventional banks because Rsquare for Islamic banks is low, but low R-square has seen in the literature. In addition to that, the autocorrelation has also been found by regression. If the value of Durbin Watson is between 1- 3 then there is no autocorrelation in the data (Muhammad et al., 2014).The value of Durbin Watson for both types of banks is around 1 which shows that data has no autocorrelation. Regarding the relationship, it has been found that capital structure is negatively correlated to ROA which is a profitability determinant for both conventional and Islamic banks. Two variables, one in conventional and one in Islamic, show contrary results but both of them are insignificant.

Our result is in line with the result of Qamar et al. (2016), Hailu (2015), Saeed, Gull and Rasheed (2013); they have also found an indirect association between capital structure and profitability. Likewise, Chechet and Olayiwola (2014); Goyal (2013); Hasan et al. (2014); and Zeitun (2012) have also found a negative relation between the performance of 
organizations and leverage. The negative relationship between ROA and leverage is due to the fact that banks in Pakistan whether Islamic or conventional are highly dependent on debt. This high percentage of debt has led to less percentage of profitability. Moreover, capital structures of both types of banks contain around $90 \%$ of debt which is a huge percentage to be considered. This negative relationship between profitability and leverage is aligned with pecking order theory which suggests a negative relation between profitability and leverage. The tables which show the relationship between ROA and the independent variable of conventional and Islamic banks are given in Table 3 and Table 4 respectively.

Table 3: ROA (Conventional banks) relationship with independent variables

${ }^{*}$ Significant at $5 \%$, ROA: Return on Assets

\begin{tabular}{|l|l|l|l|l|}
\hline Variable & Coefficient & Std. Error & t-Statistic & Prob. \\
\hline C & 0.2612 & 0.0417 & 6.2625 & 0.0000 \\
\hline LOG(DEBT_ASSET) & 0.0151 & 0.0730 & 0.2073 & 0.8366 \\
\hline LOG(DEBT_EQUITY) & -0.0344 & 0.0108 & -3.1895 & $0.0025^{*}$ \\
\hline SIZE & -0.0165 & 0.0035 & -4.7146 & $0.0000^{*}$ \\
\hline EQUITY_ASSETS & -0.1035 & 0.0344 & -3.0093 & $0.0041^{*}$ \\
\hline R-squared & 0.6236 & Mean dependent var & 0.0214 & \\
Adjusted R-squared & 0.5935 & S.D. dependent var & 0.0089 & \\
S.E. of regression & 0.0056 & Akaike info criterion & -7.4150 & \\
Sum squared resid & 0.0016 & Schwarz criterion & -7.2358 & \\
Log likelihood & 208.91 & Hannan-Quinn criter. & -7.3445 & \\
F-statistic & 20.711 & Durbin-Watson stat & 1.0070 & \\
Prob (F-statistic) & 0.0000 & & \\
\hline
\end{tabular}

Table 4: ROA (Islamic banks) relationship with independent variables *Significant at 5\%, ROA: Return on Assets

\begin{tabular}{|l|l|l|l|l|} 
Variable & Coefficient & Std. Error & t-Statistic & Prob. \\
\hline SIZE & 0.0144 & 0.0100 & 1.4425 & 0.1558 \\
\hline C & -0.2563 & 0.1000 & -2.5614 & $0.0137^{*}$ \\
\hline DEBT_EQUITY & -0.0045 & 0.0023 & -1.9479 & $0.0574^{*}$ \\
\hline LOG(DEBT_ASSET) & -0.1635 & 0.0537 & -3.0413 & $0.0038^{*}$ \\
\hline LOG(EQUITY_ASSETS) & -0.0731 & 0.0273 & -2.6706 & $0^{*}$ \\
\hline R-squared & 0.3752 & Mean dependent var & 0.0046 & \\
Adjusted R-squared & 0.3220 & S.D. dependent var & 0.0127 & \\
S.E. of regression & -0.0104 & Akaike info criterion & -6.1846 & \\
Sum squared resid & 0.0051 & Schwarz criterion & -5.9970 & \\
Log likelihood & 165.80 & Hannan-Quinn criter. & -6.1126 & \\
F-statistic & 7.0571 & Durbin-Watson stat & 1.3167 & \\
Prob (F-statistic) & 0.0001 & & \\
\hline
\end{tabular}

\subsubsection{Interpretation of Equation 2}

$$
\begin{aligned}
\mathrm{ROE}_{\mathrm{it}}= & \beta_{0 \mathrm{it}}+\beta_{1} \text { TDTTA }_{\text {it }}+\beta_{2} \text { ETTA }_{\text {it }} \\
& +\beta_{3} \text { TDTE }_{\text {it }}+\beta_{4} \text { size }+\varepsilon_{\text {it }}
\end{aligned}
$$

The result of this equation shows that independent variables of both Islamic and commercial banks show positive relation with ROE except to debt to equity in case of Islamic banks. Debt to equity, debt to asset, equity to assets and size were used for the determination of capital structure while profitability was measured by ROE in equation 2. Moreover, the R-squared is $13 \%$ and $73 \%$ for conventional banks and Islamic banks. R-squared percentage means that $13 \%$ ( conventional), and $73 \%$ ( Islamic) of profitability (ROE) is measured by the independent variables used in this study. In addition to that, the value of Durbin Watson for both types of banks is around 1 which shows that data has no autocorrelation. The same direct association between performance and the capital structure was found by Mujahid and Akhtar (2014), Saeed, Gull, and Rasheed (2013) but that was just for two variables namely, firm size and total debt to capital. Anafo et al. (2015); Chisti et al. (2013); Rajha and Alslehat (2014); Bitar et al. (2016); Pratomo and Ismail (2007); and Akhtar et al. (2011), also found a direct link between performance and size of the banks. The positive relationship between profitability's variables and leverage conforms to trade-off theory which states that by balancing debt in the capital structure, organizations can make maximum profit. Equation 2 suggests that due to the presence of debt in the capital structure, ROE of the banks goes higher. The relationship between ROE and the independent variable of conventional and Islamic banks is shown in Table 5 and Table 6 respectively. 
Table 5: LROE (Conventional banks) relationship with independent variables *Significant at 5\%, LROE: Log Return on Equity

\begin{tabular}{|l|l|l|l|l|}
\hline Variable & Coefficient & Std. Error & t-Statistic & Prob. \\
\hline LAGDTE & 0.1345 & 0.0528 & 2.5449 & $0.0143^{*}$ \\
\hline LAGETA & 19.4047 & 7.1445 & 2.7160 & $0.0092^{*}$ \\
\hline R-squared & -4.5801 & 1.1844 & -3.8667 & 0.0003 \\
Adjusted R-squared & 0.1380 & Mean dependent var & -1.4391 \\
S.E. of regression & 0.1013 & S.D. dependent var & 0.2347 \\
Sum squared resid & 0.2225 & Akaike info criterion & -0.1092 \\
Log likelihood & 2.3276 & Schwarz criterion & 0.0054 \\
F-statistic & 5.7323 & Hannan-Quinn criter. & -0.0656 \\
Prob (F-statistic) & 3.7642 & Durbin-Watson stat & 1.1365 \\
\end{tabular}

Table 6: LROE (Islamic banks) relationship with independent variables

*Significant at $5 \%$, LROE: Log Return on Equity

\begin{tabular}{|l|l|l|l|l|}
\hline Variable & Coefficient & Std. Error & t-Statistic & Prob. \\
\hline DTA & 0.2883 & 0.1321 & 2.1812 & $0.0371^{*}$ \\
\hline DTE & -6.1370 & 1.5598 & -3.9343 & $0.0005^{\star}$ \\
\hline ETA & 5.7705 & 0.9259 & 6.2321 & $0.0000^{*}$ \\
\hline SIZE & 0.0869 & 1.5577 & 0.0558 & 0.9558 \\
\hline R-squared & -1.9123 & 9.8849 & -0.1934 & 0.8479 \\
Adjusted R-squared & 0.7386 & Mean dependent var & -2.2315 \\
S.E. of regression & 0.7037 & S.D. dependent var & 2.5728 \\
Sum squared resid & 1.4003 & Akaike info criterion & 3.6428 \\
Log likelihood & 58.8271 & Schwarz criterion & 3.8650 \\
F-statistic & -58.7498 & Hannan-Quinn criter. & 3.7195 \\
Prob (F-statistic) & 21.1944 & Durbin-Watson stat & 1.6456 \\
\end{tabular}

\subsubsection{Interpretation of Equation 3}

$$
\begin{aligned}
\mathrm{EPS}_{\text {it }}= & \beta_{0 \mathrm{it}}+\beta_{1} \text { TDTTA }_{\text {it }}+\beta_{2} \mathrm{ETTA}_{\mathrm{it}} \\
& +\beta_{3} \text { TDTE }_{\mathrm{it}}+\beta_{4} \text { size }+\varepsilon_{\text {it }}
\end{aligned}
$$

The relationship between EPS, a determinant of profitability, and leverage show conflicting results. There is an indirect relation between the capital structure variables and EPS for conventional banks while the Islamic variables show opposing results; two of them show indirect relation and the rest of the two variables show direct relation. Debt to equity, debt to asset, equity to assets and size were used for the determination of capital structure while profitability was measured by EPS in equation 3. Moreover, the value of Durbin Watson for both types of banks is around 1 which shows that data has no autocorrelation. The same indirect relation between EPS and capital structure is shown by Sivathasan and Rathika. (2013). Some of the independent variables representing capital structure for Islamic banks show direct relation. The direct relation between size and performance was also found by Anafo et al. (2015).Along with Mujahid and Akhtar (2014) who found not only the positive relation between size and performance but also the direct relation between debt to equity and performance's determinant like EPS, ROA and ROE. The relationship of leverage and EPS shows that both the theories of capital structure which are under consideration of this study are true for equation 3. There is an indirect relationship between EPS and leverage in case of conventional banks which suggests that pecking order theory is true for this relationship. Furthermore, there is a positive relationship found between EPS and leverage of the Islamic banks which shows that trade-off theory exists. The relationship between EPS and the independent variable of conventional and Islamic banks is shown in Table 7 and Table 8 respectively. 
Table 7: EPS (Conventional banks) relationship with independent variables ${ }^{*}$ Significant at 5\%, EPS: Earning per share

\begin{tabular}{|l|l|l|l|l|}
\hline Variable & Coefficient & Std. Error & t-Statistic & Prob. \\
\hline C & 37.7983 & 36.7476 & 1.0285 & 0.3088 \\
\hline LOG(DEBT_ASSET) & 42.6220 & 64.3181 & 0.6626 & 0.5106 \\
\hline LOG(DEBT_EQUITY) & -26.3684 & 9.5284 & -2.7673 & $0.0079^{*}$ \\
\hline SIZE & 5.7394 & 3.0899 & 1.8574 & 0.0691 \\
\hline EQUITY_ASSETS & -75.7140 & 30.3057 & -2.4983 & $0.0158^{*}$ \\
\hline R-squared & 0.4114 & Mean dependent var & 15.406 \\
Adjusted R-squared & 0.3643 & S.D. dependent var & 6.2830 \\
S.E. of regression & 5.0091 & Akaike info criterion & 6.1469 \\
Sum squared resid & 1254.602 & Schwarz criterion & 6.3294 \\
Log likelihood & -164.0407 & Hannan-Quinn criter. & & \\
F-statistic & 8.7390 & Durbin-Watson stat & & \\
Prob (F-statistic) & 0.0000 & & 0.4782 \\
\end{tabular}

Table 8: EPS (Islamic banks) relationship with independent variables ${ }^{*}$ Significant at 5\%, EPS: Earning per share

\begin{tabular}{|l|l|l|l|l|}
\hline Variable & Coefficient & Std. Error & t-Statistic & Prob. \\
\hline LDTA & -6.2484 & 1.5054 & -4.1506 & $0.0001^{*}$ \\
\hline LDTE & 6.1439 & 1.5207 & 4.0401 & $0.0002^{*}$ \\
\hline LETA & -5.8294 & 1.3342 & -4.3692 & $0.0001^{*}$ \\
\hline LSIZE & 8.2267 & 1.8033 & 4.5618 & $0.0000^{*}$ \\
\hline C & -14.6759 & 3.3246 & -4.4143 & 0.0000 \\
\hline R-squared & 0.4503 & Mean dependent var & 1.2481 \\
Adjusted R-squared & 0.4054 & S.D. dependent var & 0.3948 \\
S.E. of regression & 0.3044 & Akaike info criterion & 0.5474 \\
Sum squared resid & 4.5421 & Schwarz criterion & 0.7316 \\
Log likelihood & -9.7818 & Hannan-Quinn criter. & 0.6185 \\
F-statistic & 10.0355 & Durbin-Watson stat & 1.1974 \\
Prob (F-statistic) & 0.0000 & & \\
\end{tabular}

\subsection{Results}

\subsubsection{Similarity/Difference of Capital Structure of Islamic and Conventional Banks}

This study includes four capital structure's variables, in which three of them, debt to equity, debt to assets and equity to assets, showed no significant difference between capital structure of Islamic and conventional banks while one of them shows significantly different result. The same capital structure of the banks might be because of operating in the same environment having the same rules and regulations from the government of Pakistan. Thus our null hypothesis is approved.

H0: Capital structure of both conventional and Islamic banks is the same.

\subsubsection{Impact of Capital Structure on the Performance of Islamic and Conventional Banks}

Regression results show that there exist some relationship, either positive or negative, between capital structure's variables and performance. ROA, a determinant of profitability, shows an indirect relationship with all variables of capital structure. In contrast, ROE exhibits a positive relation with independent variables except for one variable in Islamic banks. Furthermore, EPS has shown a negative relationship with capital structure variables while Islamic banks show a mixed relationship, for some variables it shows positive relation and for others it is negative. So, all the null hypotheses which declare that there is no significant relationship between capital structure and performances are rejected while all alternate hypotheses are accepted which state that there exists a relationship between capital structure and performance.

H1: There is a significant impact of capital structure on the ROA of Islamic and conventional banks.

H2: There is a significant impact of capital structure on ROE of Islamic and conventional banks.

H3: There is a significant impact of capital structure on EPS of Islamic and conventional banks

\section{Conclusion}

The Empirical analysis of this study states that the capital structure of both conventional and Islamic banks is similar which conforms to the finding of Meero (2015). Moreover, the performance determinant, ROA, was 
negatively correlated with leverage which is aligned with the study of Chechet and Olayiwola (2014); Goyal (2013); Hasan et al. (2014); and Zeitun (2012). The result of this relationship proves the pecking order theory which suggests a negative relation between profitability and leverage. Furthermore, there was a direct relation found between ROE and leverage, and this relation was also found by Anafo et al. (2015); Chisti et al. (2013); Rajha and Alslehat (2014); Bitar et al. (2016); Pratomo and Ismail (2007); and Akhtar et al. (2011).This direct relation validates the presence of trade-off theory which deals with a direct relation between the performance of an organization and debt. In addition to that, EPS showed contradictory results between profitability and leverage. In the case of conventional banks, there was a direct relation found between profitability and performance while Islamic banks showed indirect relation. Besides, it has been found that EPS is positively correlated with bank size which shows the economies of scale because banks having maximum age in the market are comparatively perform well in the market due to heavy investment, maximum customers, and diverse market. Thus, it is observed that capital structure has an influence on the performance/profitability of both commercial and Islamic banks and managers should carefully adjust the capital structure to get maximum profit.

\section{Recommendations}

This study covers the impact of capital structure on profitability of Islamic and conventional banks during 20062016. However, the variables used in this respective study do not consider the study from every angle and yet this topic can be researched considering some more variables, especially allowing some macroeconomic variables like GDP, exchange rates and inflation. Moreover, the two dependent variables in this study have somewhat gauged the organization in the same manner; it should be changed in future research for more handy results.

\section{References}

Addae, A. A., Nyarko-Baasi, M. N., \& Hughes, D. (2013). The effects of capital structure on profitability of listed firms in Ghana. European Journal of Business and Management, 5(31), 215-229.

Akhtar, M. F., Ali, K., \& Sadaqat, S. (2011). Liquidity risk management: A comparative study between conventional and Islamic banks in Pakistan. Interdisciplinary Journal of Research in Business, 1(1), 35-44.

Anafo, S. A., Amponteng, E., \& Yin, L. (2015). The impact of capital structure on profitability of banks listed on the Ghana Stock Exchange. Research Journal of Finance and Accounting, 6(16), 26-34.

Appiadjei, E. A. (2014). Capital structure and firm performance: Evidence from Ghana. Research Journal of Finance and Accounting, 5(16), 37-43.

Arulvel, K. K., \& Ajanthan, A. (2013). Capital structure and financial performance: A study of listed trading companies in Sri Lanka. South Asian Academic Research Journal, 3(6), 1-13.

Bitar, M., Hassan, M. K., Pukthuanthong, K., \& Walker, T. (2016). The performance of Islamic vs. conventional banks: A note on the suitability of capital ratios (Working paper). Montreal, QC: John Molson School of Business, Concordia University.

Brounen, D., \& Eichholtz, P. M. (2001). Capital Structure Theory: Evidence from Eruopean property companies' capital offering. Real Estate Economics, 29(4), 615-632.

Chechet, I. L., \& Olayiwola, A. B. (2014). Capital structure and profitability of Nigerian quoted firms: The Agency Cost Theory perspective. American International Journal of Social Science, 3(1), 139-158.

Chisti, K. A., Ali, K., \& Sangmi, M. D. (2013). Impact of capital structure on profitability of listed companies (evidence from india). The USV Annals of Economics and Public Administration, 13(1), 183-191.

Gharaibeh, A. M. (2015). The effect of capital structure on the financial performance of listed companies in Bahrain Bourse. Journal of Finance and Accounting, 3(3), 50-60.

Goyal, A. (2013). Impact of capital structure on performance of listed public sectors in India. International Journal of Business and Management Invention, 2(10), 35-43.

Hailu, A. (2015). The impact of capital structure on profitability (Doctorial dissertation, Addis Ababa University).

Hasan, M. B., Ahsan, A. F. M. M., Rahaman, M. A., \& Alam, M. L. (2014). Influence of capital structure on firm performance: Evidence from Bangladesh. International Journal of Business and Management, 9(5), 184-194. DOI:10.5539/ijbm.v9n5p184

Ibrahim, M. (2015). Measuring the financial performance of Islamic Banks. Journal of Applied Finance \& Banking, 5(3), 93-104.

Kim, S.-S., \& Lee, J.-H. (2017). Capital structure adjustment in Korean retail firms. Journal of Distribution Science, 15(11), 41-48.

Lee, J.-H., \& Liu, W.-S. (2015). Pecking order prediction of debt changes and its implication for the retail firm. Journal of Distribution Science, 13(10), 73-82.

Meero, A. A. (2015). The relationship between capital structure and performance in Gulf Countries Banks: A comparative study between Islamic Banks and Conventional Banks. International Journal of Economics and Finance, 7(12), 140-154.

Muhammad, H., Shah, B., \& Islam, Z. U. (2014). The impact of capital structure on firm performance: Evidence from Pakistan. Journal of Industrial Distribution \& Business, 5(2), 13-20.

Mujahid, M., \& Akhtar, K. (2014). Impact of capital structure on firms financial performance and shareholders wealth: Textile sector of Pakistan. 
International Journal of Learning and Development, 4(2), 27-33.

Nguyen, T., \& Nguyen, H.-C. (2015). Capital structure and firms' performance: Evidence from Vietnam's Stock Exchange. International Journal of Economics and Finance, 7(12), 1-10.

Pratomo, W. A., \& Ismail, A. G. (2007). Islamic bank performance and capital structure (No. 6012). Munich, Germany: University Library of Munich. Retrieved from https://mpra.ub.unimuenchen.de/6012/1/MPRA_paper_6012.pdf

Qamar, M. A., Masood, S., \& Khan, M. M. (2016). Impact of capital structure on profitability of commercial banks listed on Karachi Stock Exchange. International Journal of Empirical Finance, 5(2), 78-87.

Rafique, M. (2011). Effect of profitability \& financial leverage on capital structure: A case of Pakistan's automobile industry. Economics and Finance Review, 1(4), 50-58.

Rajha, D. S., \& Alslehat, D. Z. (2014). The effect of capital structure on the performance of Islamic banks. Interdisciplinary Journal of Contemporary Research in Business, 5(9), 144-161.

Saeed, M. M., Gull, A. A., \& Rasheed, M. Y. (2013). Impact of capital structure on banking performance. Interdisciplinary Journal of Contemporary Research in
Business, 4(10), 393-401.

Sakti, M., Tareq, M., Saiti, B., \& Akhtar, T. (2017). Capital structure of Islamic banks: A critical review of theoretical and empirical research. Qualitative Research in Financial Markets, 9(3), 292-308.

Sivathasan, N., \& Rathika, S. (2013). Capital structure and EPS: A study on selected financial institutions listed on Colombo Stock Exchange (CSE) in Sri Lanka. European Journal of Business and Management, 5(14), 69-73.

Zafar, M. R., Zeeshan, F., \& Ahmed, R. (2016). Impact of capital structure on banking profitability. International Journal of Scientific and Research Publications, 6(3), 186-193.

Zarrouk, H., Jedidia, K. B., \& Moualhi, M. (2016). Is Islamic bank profitability driven by same forces as conventional banks? International Journal of Islamic and Middle Eastern Finance and Management, 9(1), 46 66.

Zeitun, R. (2012). Determinants of Islamic and Conventional Banks performance in GCC countries using panel data analysis. Global Economy and Finance Journal, 5(1), 53-72.

Zeitun, R., \& Tian, G. G. (2007). Capital structure and corporate performance: Evidence from Jordan. Australasian Accounting, Business and Finance Journal, l(4), 40-61. http://dx.doi.org/10.14453/aabfj.v1i4.3 